\title{
Part II In normal subjects and patients suffering from peptic ulcer and gastric carcinoma
}

Recent studies have demonstrated the presence of proteins in gastric juice (Citrin, Sterling, and Halstad, 1957; Gullberg and Olhagen, 1959; Heiksell, Wada, Stempien, Fukuda, Nakagawa, Yachi, Dagradi, and Carpenter, 1961; Glass and Ishimori, 1961; Piper, Stiel, and Builder, 1962), and the presence of excess albumin loss into the gastrointestinal tract in gastric carcinoma has been demonstrated by Jarnum and Schwartz (1960). Estimation of protein loss into the small and large intestine, due to problems of collection, will always involve complex procedures and depend upon assumptions that may not always be justified. However, gastric juice can be collected by continuous suction and the protein concentration estimated by conventional biochemical procedures. As no such study has been carried out, the present investigation was undertaken of the protein concentration and output in gastric juice in a series of control subjects and in patients suffering from gastric carcinoma, gastric ulcer, and duodenal ulcer, both under basal and stimulated conditions; gastric juice was collected by continuous suction and the protein concentration estimated using the biuret reaction.

\section{METHODS AND MATERIALS}

The patients studied included a group of 10 control subjects, who were relatively healthy hospital in-patients free of diseases of the gastrointestinal tract, liver disease, haemopoietic disease, and heart failure, and 27 gastric ulcer patients, five duodenal ulcer patients, and 14 patients with gastric carcinoma. The patients suffering from gastric and duodenal ulcer and gastric carcinoma were diagnosed on criteria previously defined (Piper, Macoun, Broderick, Fenton, and Builder, 1963). Serum proteins were determined in the patients suffering from gastric carcinoma.

The technique of collection of gastric juice has been previously described (Piper et al., 1963). It involved the collection by continuous suction of two 15-minute basal specimens and two 15-minute specimens after stimulation of gastric secretion using $0.02 \mathrm{mg}$. histamine acid phosphate per kilogram of body weight subcutaneously; the extragastric effects of histamine were inhibited by $100 \mathrm{mg}$. of Anthisan injected intramuscularly 20 minutes previously.

Protein concentration was determined using the biuret reaction and the method of Gornall, Bardawill, and David (1949), and D.N.A. by the method of Ceriotti (1952). Bile- and blood-stained specimens were discarded; 17 basal specimens were discarded because of contamination.

\section{RESULTS}

The specimens chosen for comparison were the second basal specimen and the second specimen after histamine stimulation. A comparison of the protein concentrations and output in these specimens is shown in Fig. 2 and in Table II.

It is seen that carcinoma patients had significantly higher protein concentration in their gastric juice in basal specimens than control subjects and duodenal ulcer and gastric ulcer patients; gastric ulcer patients had a significantly higher basal concentration than duodenal ulcer patients. In the post-histamine specimens, duodenal ulcer patients showed protein concentrations significantly less than did carcinoma and gastric ulcer patients. The post-

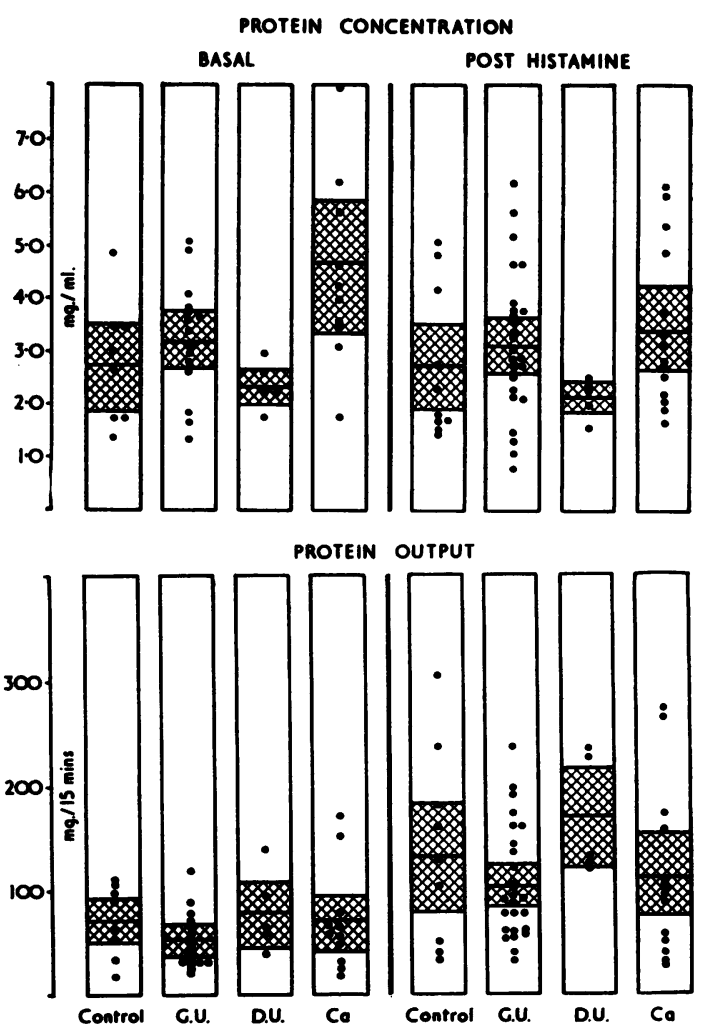

FIG. 2. Protein concentration and output in basal and post-histamine gastric secretion in control subjects and gastric ulcer, duodenal ulcer, and carcinoma patients. The shaded area represents the mean \pm 2 S.E. 
TABLE II

SIGNIFICANCE OF DIFFERENCES IN PROTEIN CONCENTRATION AND OUTPUT IN GASTRIC ULCER, GASTRIC CARCINOMA, AND CONTROL SUBJECTS

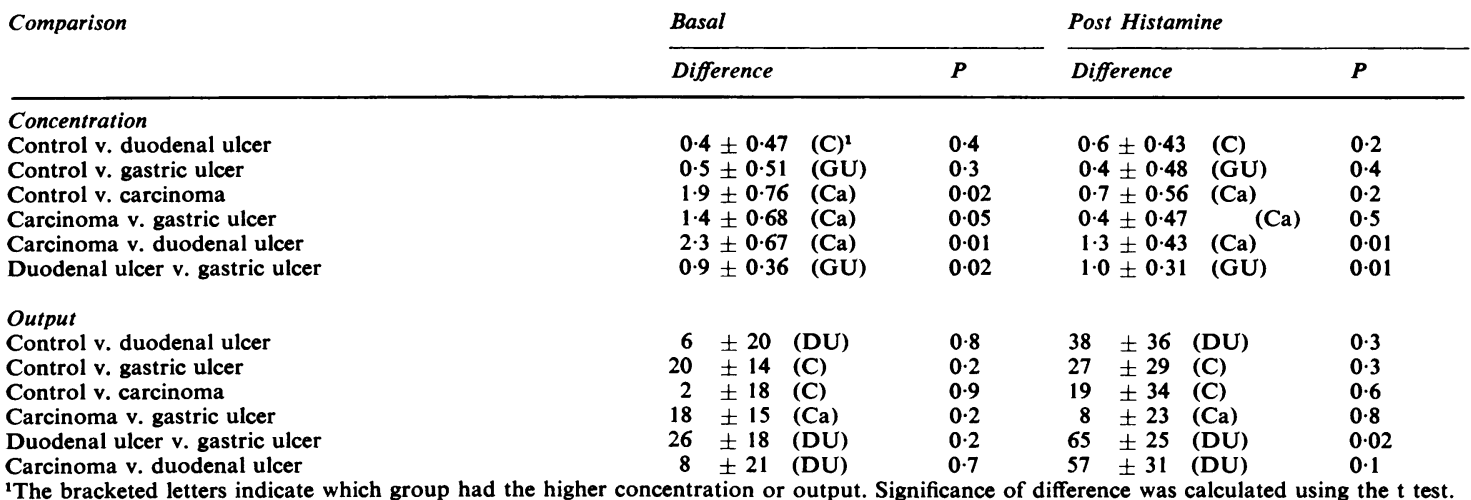

histamine protein concentrations were statistically similar in controls and carcinoma patients, controls and gastric ulcer patients, controls and duodenal ulcer patients, and carcinoma and gastric ulcer patients. The concentration was significantly lower in duodenal ulcer patients when the latter were compared with gastric ulcer and gastric carcinoma patients. The basal protein output was similar in all groups. The post-histamine protein output was also similar in all groups except that duodenal ulcer patients had a greater output than gastric ulcer patients.

Owing to technical difficulties initially, D.N.A. concentration was not determined in all specimens. The mean D.N.A. concentration in controls, gastric ulcer, gastric carcinoma, and duodenal ulcer patients was respectively in the basal specimens $38 \pm 2$, $82 \pm 22,124 \pm 48$ and $26 \pm \mu \mathrm{g} . / \mathrm{ml}$. and in the histamine-stimulated specimens $15 \pm 3, \quad 52 \pm 2$, $41+7$, and $13 \pm 5 \mu \mathrm{g}$. $/ \mathrm{ml}$. There was no significant correlation between the D.N.A. and protein concentration in the gastric juice in the basal or posthistamine specimens in the whole group $(P=0.6$ and $P=0.2$ respectively).

Serum proteins were determined in 11 gastric carcinoma patients. The serum albumin concentration varied between 3.0 g. $\%$ and 4.1 g. $\%$ with a mean of $3.4 \pm 0 \cdot 2$ (Table III). There was no significant correlation between the serum albumin concentration and the basal protein loss $(r=0.13$, $P=0.8$ ); however, the normal serum albumin levels in all patients made a statistical correlation between these two variables unlikely with a small number of patients in the group.

\section{DISCUSSION}

The demonstration of protein loss into the stomach
TABLE III

SERUM PROTEIN CONCENTRATIONS AND BASAL PROTEIN CONCENTRATIONS AND OUTPUT IN THE GASTRIC JUICE OF GASTRIC CARCINOMA PATIENTS ${ }^{1}$

\begin{tabular}{|c|c|c|c|c|}
\hline \multirow[t]{2}{*}{ Case No. } & \multicolumn{2}{|c|}{ Serum Proteins } & \multicolumn{2}{|c|}{$\begin{array}{l}\text { Basal/Proteins in Gastric } \\
\text { Juice }\end{array}$} \\
\hline & $\begin{array}{l}\text { Albumin } \\
(g . \%)\end{array}$ & $\begin{array}{l}\text { Globulin } \\
(g . \%)\end{array}$ & $\begin{array}{l}\text { Concentra- } \\
\text { tion }(m g . \%)\end{array}$ & Output (mg.) \\
\hline 1 & $3 \cdot 2$ & $2 \cdot 2$ & $10 \cdot 0$ & 150 \\
\hline 2 & $3 \cdot 8$ & $2 \cdot 4$ & 3.4 & 54 \\
\hline 3 & $4 \cdot 1$ & 3.4 & 3.9 & 47 \\
\hline 4 & 3.4 & $2 \cdot 8$ & $4 \cdot 2$ & 168 \\
\hline 5 & $3 \cdot 7$ & 1.9 & $5 \cdot 0$ & 30 \\
\hline 6 & 3.6 & $2 \cdot 7$ & $3 \cdot 5$ & 63 \\
\hline 7 & 3.4 & 2.9 & $5 \cdot 6$ & 73 \\
\hline 8 & $3 \cdot 2$ & 3.4 & 3.0 & 64 \\
\hline 9 & $3 \cdot 2$ & 3.7 & $4 \cdot 5$ & 23 \\
\hline 10 & 3.0 & $2 \cdot 6$ & 1.6 & 16 \\
\hline 11 & 3.4 & $3 \cdot 1$ & 3.6 & 120 \\
\hline
\end{tabular}
serum proteins and basal gastric juice proteins determined.

was first demonstrated by Citrin et al. (1957) in a patient with giant hypertrophy of gastric mucosa using radioiodinated serum albumin. Its presence was subsequently fully confirmed using electrophoretic and immunological techniques (Heiskell et al., 1961; Glass and Ishimori, 1961; Gullberg and Olhagen, 1959; Piper et al., 1962). Immunological and electrophoretic techniques can be partially invalidated by intragastric autodigestion (Piper et al., 1962) and intragastric neutralization to prevent autodigestion makes quantitative studies of protein concentrations and output impossible. Fortunately digestion of protein by pepsin does not interfere with these estimations by the biuret reaction and consequently gastric juice protein can be directly measured.

The failure to demonstrate excess protein loss into the gastric juice of gastric carcinoma patients may 
initially appear to be at variance with the findings of Jarnum and Schwartz (1960) who demonstrated excess PVP.131I excretion in patients with gastric carcinoma. However, the cases studied by the latter workers were nine patients who had a serum albumin that varied between 2 and $3 \mathrm{~g}$. per $100 \mathrm{ml}$; seven of these showed abnormal faecal excretion of PVP_131I. The group investigated in the present study, with the exception of one patient who had a serum albumin level of $3 \mathrm{~g} . \%$, all had serum albumin levels in excess of $3 \mathrm{~g} . \%$, and the apparent discrepancy between our results and those of Jarnum and Schwartz (1960) can be explained by a difference in the type of patient investigated. The failure to demonstrate a correlation between the serum albumin level and the protein output in gastric juice in the present study can be explained by the small number studied, the normal serum albumin concentration present, and the presence of other factors that influence serum albumin levels apart from gastrointestinal protein loss, such as protein intake and endogenous protein breakdown, and hepatic function.

The mechanism of protein loss into the gastrointestinal tract is unknown; possible mechanisms existing normally have been discussed by Hollander and Horowitz (1962). It is tempting to suggest that the loss in carcinoma may be due to blood loss. However, blood staining was not present in the specimens examined and specimens of dilutions of blood containing similar protein concentrations show marked blood staining. Also it is the impression of others who have studied protein loss into the stomach in carcinoma that blood loss does not make a significant contribution to the protein content of gastric juice (Heiskell et al., 1961; Schwartz and Jarnum, 1959; Turner, Sowry, and O'Donnell, 1963). The lack of positive correlation between protein and D.N.A. output in gastric juice suggests that cell desquamation is not the predominant origin of the protein content of gastric juice. An undetermined amount enters as the protein moiety of mucus and some is also secreted.

It is of some interest to compare the extent of protein elimination into the stomach shown in this study with total protein and albumin turnover rates and studies of albumin loss into the stomach using other techniques. The mean control protein loss into the stomach in the present study was $7 \cdot 7 \mathrm{~g}$. per day, with a range extending from approximately $1 \mathrm{~g}$. per day in a control patient to $16 \mathrm{~g}$. per day in a patient with carcinoma of the stomach. Previous studies have shown that, electrophoretically, about $27 \%$ of the protein-staining material in gastric juice in normal subjects has the electrophoretic mobility of albumin (Piper et al., 1962). This would indicate a mean normal albumin loss into the stomach of approximately 2 g. per day. Using ${ }^{131}$ Ilabelled albumin, the absolute albumin turnover rate has been shown to lie between 6 and $10 \mathrm{~g}$. per day (Wilkinson and Medenhall, 1963; Jeejeebhoy and Coghill, 1961). Also Wetterfors, Gullberg, Liljedahl, Plantin, Birke, and Olhagen (1960) have demonstrated, using ${ }^{131}$ I-labelled albumin, that at least $1 \mathrm{~g}$. and possibly $2.6 \mathrm{~g}$. of albumin was eliminated through the stomach wall per 24 hours; it was also found that the jejunum eliminated $6 \mathrm{~g}$. albumin per day in a group of patients whose total body albumin catabolism was $12 \mathrm{~g}$. per day. Total protein turnover per day has been calculated to be in the order of 5 to $10 \mathrm{~g}$. protein per kg. per day (Waterlow, 1962). It is seen that the results of this study are consistent with other studies using different techniques and emphasize the important role of the stomach in protein metabolism. Unlike protein lost into the colon, protein lost into the stomach normally is digested and reabsorbed. However, the loss of up to $16 \mathrm{~g}$. per protein day in some patients with persistent vomiting or on continuous gastric suction justifies consideration when the metabolic needs of these patients are considered.

\section{SUMMARY}

Examination of protein concentration and output in basal and histamine-stimulated gastric juice shows that gastric carcinoma patients have significantly higher protein concentration in their gastric juice in basal specimens than control subjects, duodenal ulcer patients, and gastric ulcer patients; gastric ulcer patients have significantly higher basal protein concentrations than duodenal ulcer patients. In stimulated gastric juice, duodenal ulcer patients have significantly lower protein concentration than gastric ulcer and gastric carcinoma patients. As regards protein output in the four groups studied, duodenal ulcer patients in histamine-stimulated secretion show a greater protein output than gastric ulcer patients; all protein outputs in the basal secretion were statistically similar.

There was no correlation between D.N.A. and the protein content of gastric juice.

The protein lost into the stomach may vary between 1 and $16 \mathrm{~g}$. per day and the important role of the stomach in protein metabolism is emphasized.

The work was supported by the Damon Runyon Memorial Fund for Cancer Research (Inc.) grant no. 761, the New South Wales State Cancer Council, and the Cancer Research Fund of the University of Sydney. The helpful advice of Professor C. R. B. Blackburn, Professor of Medicine, the University of Sydney, is gratefully acknowledged. 


\section{REFERENCES}

Ceriotti, G. (1952). A microchemical determination of desoxyribonucleic acid. J. biol. Chem., 198, 297-303.

Citrin, Y., Sterling, K., and Halsted, J. A. (1957). The mechanism of hypoproteinemia associated with giant hypertrophy of the gastric mucosa. New Engl. J. Med., 257, 906-912.

Glass, G. B. J., and Ishimori, A. (1961). Passage of serum albumin into the stomach. Its detection by paper electrophoresis of gastric juice in protein-losing gastropathies and gastric cancer. Amer. J. dig. Dis., 6, 103-133.

Gornall, A. G., Bardawill, C. J., and David, M. M. (1949). Determination of serum proteins by means of the biuret reaction. $J$. biol. Chem., 177, 751-766.

Gullberg, R., and Olhagen, B. (1959). Electrophoresis of human gastric juice. Nature (Lond.), 184, 1848-1849.

Heiskell, C. L., Wada, T., Stempien, S. J., Fukuda, M., Nakagawa, S., Yachi, A., Dagradi, A., and Carpenter, C. M. (1961). Normal serum proteins in gastric juice. Gastroenterology, 40, 775-781.

Hollander, F., and Horowitz, M. I. (1962). Serum proteins in gastric mucus and other secretions. Ibid., 43, 75-83.

Jarnum, S., and Schwartz, M. (1960). Hypoalbuminemia in gastric carcinoma. Ibid., 38, 769-776.

Jeejeebhoy, K. N., and Coghill, N. F. (1961). The measurement of gastrointestinal protein loss by a new method. Gut, 2, 123-130.
Piper, D. W., and Fenton, B. H. (1965). The effect of peptic digestion and acid hydrolysis of albumin on its concentration as determined by the biuret reaction. In preparation.

-, Macoun, M. L., Broderick, F. L., Fenton, B. H., and Builder, J. E. (1963). The diagnosis of gastric carcinoma by the estimation of enzyme activity in gastric juice. Gastroenterology, 45, 614-620.

-, Stiel, M. C., and Builder, J. E. (1962). The electrophoresis of human gastric juice. Gut, 3, 349-360.

Schwartz, M., and Jarnum, S. (1959). Gastrointestinal protein loss in idiopathic (hypercatabolic) hypoproteinaemia. Lancet, 1, 327-330.

Turner, P., Sowry, G. S. C., and O'Donnell, P. M. (1963). Hypoalbuminaemia due to protein loss from gastric carcinoma. Gut, 4, 155-157.

Waterlow, J. C. (1962). Protein malnutrition and replenishment with protein in man and animals. In Protein Metabolism, International Symposium edited by F. Gross, pp. 90-108. Springer, Berlin.

Wetterfors, J., Gullberg, R., Liljedahl, S. O., Plantin, L. O., Birke, G., and Olhagen, B. (1960). Role of the stomach and small intestine in albumin breakdown. Acta med. scand., 168, 347-363.

Wilkinson, P., and Medenhall, C. L. (1963). Serum albumin turnover in normal subjects and patients with cirrhosis measured by $I^{131}$-labelled human albumin. Clin. Sci., 25, 281-292. 